\title{
Effect of Biochar Amendment on Bioavailability and Accumulation of Cadmium and Trace Elements in Brassica chinensis L. (Chinese Cabbage)
}

\author{
Kiran Yasmin Khan ${ }^{1}$, Barkat $\mathrm{Ali}^{2,3}$, Xiaoqiang Cui ${ }^{1}$, Ying Feng ${ }^{1}$, Peter Joseph Stoffella ${ }^{4}$, Fengshan Pan $^{1}$, Lin Tang ${ }^{1}$ \\ \& Xiaoe Yang ${ }^{1}$ \\ ${ }^{1}$ Ministry of Education Key Laboratory of Environmental Remediation and Ecological Health, College of \\ Environmental and Resource Sciences, Zhejiang University, Hangzhou, China \\ ${ }^{2}$ The State Key Laboratory of Food Science and Technology, School of Food Science and Technology, Jiangnan \\ University, Wuxi, China \\ ${ }^{3}$ National Agricultural Research Centre, Islamabad, Pakistan \\ ${ }^{4}$ Indian River Research and Education Center, Institute of Food and Agricultural Sciences, University of Florida, \\ Fort Pierce, Florida, USA \\ Correspondence: Xiaoe Yang, Ministry of Education Key Laboratory of Environmental Remediation and \\ Ecological Health, College of Environmental and Resource Sciences, Zhejiang University, Hangzhou, China. \\ E-mail: xeyang@zju.edu.cn
}

Received: June 6, 2016

Accepted: July 19, $2016 \quad$ Online Published: August 15, 2016

doi:10.5539/jas.v8n9p23

URL: http://dx.doi.org/10.5539/jas.v8n9p23

\begin{abstract}
This study aims to investigate the potential use of maize stalk (MS), bamboo (BB) and cow manure (CM) derived biochar as a soil amendment on the cadmium $(\mathrm{Cd})$ and trace metals $(\mathrm{Mn}, \mathrm{Zn}, \mathrm{Fe})$ accumulation by two $\mathrm{Cd}$ accumulator cultivars; low (Aijiaoheiye 333) (AJ) and high (Zhouyeheiyoudonger) (ZH) of Brassica chinensis $\mathrm{L}$. The effect of different biochar $(4 \% \mathrm{w} / \mathrm{w})$ on both cultivars grown on artificially Cd contaminated Alfisol soil was studied. All selected biochar decreased the bioavailability of $\mathrm{Cd}$ in soil and its phytoavailability for both cultivars of $B$. chinensis L. followed the order: $\mathrm{MS}>\mathrm{CM}>\mathrm{BB}$. In particular, with increase soil pH MS biochar significantly reduced $\mathrm{Cd}$ bioavailability in soil by $54 \%$ and accumulation in shoots of $\mathrm{AJ}$ and $\mathrm{ZH}$ cultivars by $35 \%$ and $41 \%$, as soil amendment. These results indicated the effectiveness of biochar by reducing the availability and phytotoxicity of $\mathrm{Cd}$, while enhanced shoot dry biomass by promoting microbial activity and availability of essential trace metals.
\end{abstract}

Keyword: bamboo, cow manure, maize stalk, immobilization, soil contamination, trace metal

\section{Introduction}

Cadmium $(\mathrm{Cd})$ contamination in soil, sediment and water has become a major environmental issue due to its higher toxicity and mobility to plants and further in the food chain (Tang et al., 2009), and has become a major human health problem when those soils are used in agriculture purpose to produce food for human consumption (Lee et al., 2005; Liu et al., 2005). Due to higher mobility of Cd in soil-plant system, it is easily taken up in edible parts of plants. Leafy vegetables are commonly consumed by human as a source of food and accumulate higher concentrations of $\mathrm{Cd}$ as compared to other crops (Yang et al., 2010). Brassica chinensis L. known as Chinese cabbage is an important leafy vegetable grown and consumed throughout the world; especially in China. Chinese cabbage grown in $\mathrm{Cd}$ contaminated soil has higher capacity to accumulate $\mathrm{Cd}$ in its edible parts, hence can pose potential health risks (Yan et al., 2009). Cd minimization is set priority issue in China to avoid serious health risks and to ensure food safety. To reduce the $\mathrm{Cd}$ contamination through the food chain, therefore it is very important to minimize $\mathrm{Cd}$ pollution and its availability in soils.

Minimum Cd accumulation in edible parts of crop plants through soil amendments is a better approach that can directly affects its mobilization to avoid the human health risks attributed to Cd. Growing low $\mathrm{Cd}$ accumulating cultivars of crops with soil amendments may be more efficient for reducing $\mathrm{Cd}$ entrance in food chain as compared to growing low-Cd cultivars alone (Liu et al., 2010). There has been increasing interest in the 
reduction of heavy metals in soils with the application of different types of biochar and biosolids amendment (Namgay et al., 2010). Biochar are stable carbonaceous by-products synthesized through pyrolysis of organic materials (Ahmad et al., 2014). They are used as soil amendment to reduce heavy metal mobility and bioavailability (Me'ndez et al., 2012), because of having various immobilization characteristics of contaminants including active functional groups, microporous structure, high $\mathrm{pH}$ and cation exchange capacity (Chen \& Lin, 2001; Jiang et al., 2012). The sorption process affected by functional groups of biochar depends on the nature of their surface charge so that both transition metals and non-transition metals can be occluded onto the surface of their particles (Amonette \& Joseph, 2009). Biochar derived from different source materials have different characteristics that affect its performance regarding to remediation capacity of $\mathrm{Cd}$. Therefore, the choice of biochar for immobilizing heavy metals, characteristics of biochar should also be taken into consideration. Several kinds of source materials can be used to make biochar; like woodchips, animal manure and crop residues (Tang et al., 2013).

Trace metals such as $\mathrm{Zn}, \mathrm{Mn}$ and Fe are essential elements to promote plant growth and required to accomplish metabolic functions, such as energy metabolism, primary and secondary metabolism, cell protection, gene regulation, hormone perception, signal transduction and reproduction (Hänsch \& Mendel, 2009; Hebbern et al., 2009). Fang et al. (2012) reported that Chinese cabbage grown in heavy metals contaminated soil is prone to decrease the nutrients uptake. However, biochar application significantly increases the amounts of essential trace metals and plant growth (Lehmann et al., 2003).

Due to the rapid industrialization and wide application of agrochemicals, China is now facing issues of heavy metal contamination in farmland soil. According to national survey of soil pollution from 2005-2013, about $6.3 \times 106 \mathrm{~km}^{2}$ of land throughout China and $19.40 \%$ of the farmland soil was polluted mainly with heavy metals (Bulletin of National Soil Pollution Survey, 2014). Alfisol is an important soil type and occupied about 1.25 million square $\mathrm{km}$, about $13 \%$ of the land area in China (about the same percentage occurred as Alfisols in U.S.) (Xiao, 1992). Plants grown in Cd contaminated Alfisol soil accumulated higher Cd contents because of relatively higher percentage of sand in this soil which enhance $\mathrm{Cd}$ accumulation and ultimately decreased eco-physiological components such as plant growth, by interfering metabolic processes, mineral nutrition and photosynthetic activity (Sebastian \& Prasad, 2014; Rafiq et al., 2014).

The effects of various biochar on immobilization of heavy metals have been studied in different soils but less information is available on plant and animal manure derived biochar effect on Cd immobilization to affirm the root uptake and shoot translocation in low and high $\mathrm{Cd}$ accumulation cultivars of Chinese cabbage grown in a $\mathrm{Cd}$ contaminated Alfisol soil. This study investigated the effects of different biochar on: 1) immobilization of Cd in a Chinese Alfisol soil, 2) their impact to availability of $\mathrm{Zn}, \mathrm{Mn}$ and Fe; 3) plant growth and metals mobility in $\mathrm{Cd}$ accumulation contrasting cultivars of Chinese cabbage.

\section{Materials and Methods}

\subsection{Biochar Production and Characterization}

Maize stalks were collected from a local grower in Hangzhou, China; bamboo saw dust was obtained from Dalian songsen products Co. Ltd and cow manure was collected from a cattle operation in Shaoxing, Zhejiang, China. The maize stalk (MS), bamboo (BB), and air dried cow manure (CM) was oven dried at $65{ }^{\circ} \mathrm{C}$ for $48 \mathrm{~h}$, prior to pyrolyzed. All biochar were produced at $500{ }^{\circ} \mathrm{C}$ pyrolysis temperature, combusted in an automated biomass pyrolyzing furnace (TH-01, China) for $2 \mathrm{hr}$ at heating rate of $10^{\circ} / \mathrm{min}$. After the pyrolysis process, the biochar were ground to pass through a $0.5 \mathrm{~mm}$ sieve. All the biochar were analyzed for $\mathrm{pH}$ by adding biochar to deionized water at the ratio of 1:20 (Inyang et al., 2012). Elemental (N, C, H) analysis was performed by using an elemental analyzer (Flash-EA112, Thermo Finnigan). For the identification of surface functional groups, FTIR analysis (Nicolet 6700) was performed in the 400 and $4000 \mathrm{~cm}^{-1}$ region with 50 scans taken at $2 \mathrm{~cm}^{-1}$ resolutions. Scanning Electron Microscope (SEM) imaging analysis by using scanning microscope (FEI QUANTA FEG 650) was performed to compare the biochar structure. Surface element analysis was done at the same surface location with SEM using energy dispersive $\mathrm{X}$-ray spectroscopy (EDS, EDAX Inc. Genesis XM). The specific surface areas of the biochar were measured by $\mathrm{N}_{2}$ adsorption isotherms at $77 \mathrm{~K}$ with the Brunauer-Emmett-Teller (BET) method and by $\mathrm{CO}_{2}$ isotherms at $273 \mathrm{~K}$ using a Quadrasorb Si-MP surface area analyzer.

\subsection{Soil and Amendments}

The soil (Alfisol) used in this study was collected from the upper horizon at a depth of up to $20 \mathrm{~cm}$ from an uncontaminated site of Shaoxing, Zhejiang, China. The soil was air-dried, grounded, screened through $2 \mathrm{~mm}$ 
sieve and analyzed for $\mathrm{pH}$ with a $\mathrm{pH}$ meter in 1:5 soil water suspensions after 30 min (Tang et al., 2015) and organic matter contents (Rashid et al., 2001). The physiochemical properties of soil are listed in Table 1.

Table 1. Physiochemical properties of soil

\begin{tabular}{lllllllll}
\hline Soil Type & Sand $\%$ & Silt $\%$ & Clay $\%$ & OM \% & Total Cd $\left(\mathrm{mg} \mathrm{kg}^{-1}\right)$ & Total Mn $\left(\mathrm{mg} \mathrm{kg}^{-1}\right)$ & Total Zn $\left(\mathrm{mg} \mathrm{kg}^{-1}\right)$ & Total Fe $\left(\mathrm{mg} \mathrm{kg}^{-1}\right)$ \\
\hline Alfisol & 45 & 25 & 24 & 3.00 & 0.05 & 60 & 79 & 70 \\
\hline
\end{tabular}

Soil was spiked with $\mathrm{Cd}$ as $\mathrm{Cd}\left(\mathrm{NO}_{3}\right)_{2}$ in an aqueous solution at the rate of $2 \mathrm{mg} \mathrm{kg}^{-1}$. Uncontaminated tap water was used in soil to maintain $70 \%$ water holding capacity for the period of two months. Each soil treatment had been sieved ( $2 \mathrm{~mm}$ sieve) again and total $\mathrm{Cd}$ concentration was determined. CM, MS and BB biochar were applied at the rate of $4 \% \mathrm{w} / \mathrm{w}$ to each $\mathrm{Cd}$ contaminated potted soil and incubated for two weeks to reach equilibrium at $60 \%$ water holding capacity (Park et al., 2011).

\subsection{Mehlich-3 Extraction}

Bioavailability of $\mathrm{Cd}$ and trace metals was determined in soils with and without biochar amendment through Mehlich-3-extraction by following the extraction method as described by Mehlich (1984). Soil samples without biochar were used as blank sample. Sample concentration in filtrate was analyzed for metals by ICP-MS (Agilent, 7500a, USA). All samples were conducted in triplicates.

\subsection{Plant and Greenhouse Experiment}

A pot experiment was performed under natural light in greenhouse at Zhejiang University (China). Two Cd accumulation contrasting cultivars of B. chinensis L. low; Aijiaoheiye 333 (AJ) and high; Zhouyeheiyoudonger (ZH) Cd accumulator cultivar (Chen et al., 2012), were used for the experiment. Sieved soil (2 kg) was placed in each $(20 \mathrm{~cm} \times 20 \mathrm{~cm})$ plastic pots set on plastic saucers. After two weeks of incubation period, 15 seeds were sown in each pot. The treatments were arranged in completely randomized design in triplicates (pots). Ten days later, uniform seedlings were thinned to three per pot. Plants were grown for two months at average temperature of $25-28^{\circ} \mathrm{C}$ with regular watering. After harvesting, plants were separated into roots and shoots (including leaves and stem) and were washed with tap water and then with Milli-Q water to remove attached soil particles. The samples were blotted dry and then dried at $65{ }^{\circ} \mathrm{C}$ for $72 \mathrm{~h}$. Dry weight (DW) of shoots was measured in triplicates.

\subsection{DHA and BSR of Soil}

At the end of the experiment, each fresh moist soil samples from pots were used to analyze soil basal respiration (SBR) and dehydrogenase activity (DHA). SBR was measured by $\mathrm{CO}_{2}$ evolution according to procedure described by Islam and Weil (2000). Briefly, about $20 \mathrm{~g}$ (dry weight basis) of each fresh soil was weighted in a plastic tube (perforate $\mathrm{d}$ at the top for gas exchange) adjusted to $60 \%$ water holding capacity and inserted in Schott bottle containing $20 \mathrm{ml} 0.5 \mathrm{M} \mathrm{NaOH}$ for 10 days at $25{ }^{\circ} \mathrm{C}$ in the dark. After incubation period, the $\mathrm{CO}_{2}$ absorbed in the $\mathrm{NaOH}$ was immediately measured by using a TOC analyzer (Analytikjena, multi N/C 3100, China). The SBR was calculated as follows:

$$
\mathrm{SBR}=\left(\mathrm{CO}_{2}-\mathrm{C}_{\text {soil }}-\mathrm{CO}_{2}-\mathrm{C}_{\text {air }}\right) / 10 \text { days }
$$

Where, $\mathrm{CO}_{2}-\mathrm{C}_{\text {soil }}$ is the amount of $\mathrm{CO}_{2}$ evolved from soil and $\mathrm{CO}_{2}-\mathrm{C}_{\text {air }}$ is the absorbed atmospheric $\mathrm{CO}_{2}$ by 0.5 $\mathrm{M} \mathrm{NaOH}$ in a blank flask.

For dehydrogenase activity (DHA) analysis, $3 \mathrm{~g}$ ( dry weight basis) of each fresh soil sample was weighed into $50 \mathrm{~mL}$ sterile centrifuge tubes with $3 \mathrm{~mL}$ of $0.5 \%$ triphenyltetrazolium chloride (TTC) solution in $0.1 \mathrm{M}$ tris buffer (pH 7.6-7.8) (Casida et al., 1964; J. Singh \& D. K. Singh, 2005). After incubation for $24 \mathrm{~h}$ at $37^{\circ} \mathrm{C}, 10$ $\mathrm{mL}$ of methanol was added to each sample, shaked and centrifuged to extract triphenyl formazan (TPF) which was measured at $485 \mathrm{~nm}$ against blank (sterile Milli-Q water) using spectrophotometer (Shimadzu C-R3A).

\subsection{Cadmium and Trace Metal Analysis}

For the determination of total $\mathrm{Cd}$ and trace metals (Fe, $\mathrm{Mn}, \mathrm{Zn}$ ) concentration in soil, $0.2 \mathrm{~g}$ of each soil sample was digested with $\mathrm{HNO}_{3}-\mathrm{HF}_{-} \mathrm{HClO}_{4}(5: 1: 1)$ (Shentu et al., 2008). Whereas, for plant samples $0.2 \mathrm{~g}$ of dried tissue of each treatment was digested in $15 \mathrm{~mL} \mathrm{HCl} / \mathrm{HNO} / \mathrm{HClO}_{4}(3: 1: 2 \mathrm{v} / \mathrm{v})$ at $150{ }^{\circ} \mathrm{C}$ until the solution became clear. After cooling the digest was transferred to a volumetric flask, diluted to $30 \mathrm{ml}$ volume (Tang et al., 
2015). Solutions were filtered and stored at $4{ }^{\circ} \mathrm{C}$ prior to analysis. Metal concentrations were analyzed in the filtrate by using ICP-MS (Agilent, 7500a). All results were conducted in triplicates.

\subsection{Statistical Analysis}

The data were analyzed by one-way analysis of variance (ANOVA) and Duncan's multiple range test was used to compare the means of the treatments using the statistical software package SPSS (version 16.0). The mean values with standard error were presented and a $P<0.05$ was considered to be statistically significant.

\section{Results}

\subsection{Characteristics of Soil and Biochar}

The $\mathrm{pH}$ of MS and CM biochar were alkaline while $\mathrm{BB}$ biochar had neutral $\mathrm{pH}$ and contains mainly $\mathrm{C}$ and a small proportion of $\mathrm{N}$. The $\mathrm{C}$ content of biochar followed the order $\mathrm{CM}<\mathrm{MS}<\mathrm{BB}$ (Table 2). These results were used to calculate the atomic $\mathrm{H}: \mathrm{C}$ and $\mathrm{C}: \mathrm{N}$ ratios to evaluate the aromaticity of biochar.

Table 2. Physiochemical properties of biochar

\begin{tabular}{|c|c|c|c|c|c|c|c|}
\hline \multirow{2}{*}{ Sample } & \multirow{2}{*}{$\mathrm{pH}$} & \multicolumn{3}{|c|}{ Component \% } & \multicolumn{2}{|c|}{ Atomic Ratio } & \multirow{2}{*}{$\mathrm{SA}\left(\mathrm{m}^{2} / \mathrm{g}\right)$} \\
\hline & & $\mathrm{C}$ & $\mathrm{H}$ & $\mathrm{N}$ & $\mathrm{H} / \mathrm{C}$ & $\mathrm{C} / \mathrm{N}$ & \\
\hline MS & 8.36 & 65.89 & 1.93 & 1.94 & 0.35 & 42.23 & 1.624 \\
\hline $\mathrm{BB}$ & 6.97 & 80.44 & 2.46 & 1.06 & 0.36 & 95.71 & 6.376 \\
\hline $\mathrm{CM}$ & 8.35 & 41.71 & 1.2 & 1.89 & 0.34 & 25.70 & 8.559 \\
\hline
\end{tabular}

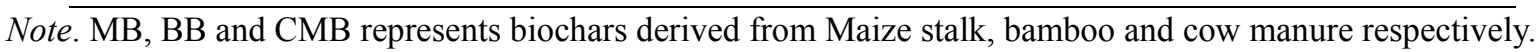

The nature of functional groups was identified in MS, BB and CM by FTIR (Fourier transform infrared spectroscopy) analysis (Figure 1). According to Coates (2000), the band at $3405 \mathrm{~cm}^{-1}$ of MS biochar represents the hydroxyl group, $\mathrm{OH}$ stretch. The band at 1418 and $1593 \mathrm{~cm}^{-1}$ represents the $\mathrm{C}=\mathrm{C}-\mathrm{C}$ aromatic ring stretch and carboxylate bond and the band at $1418 \mathrm{~cm}^{-1}$ represents the vinyl C-H in plane bends of olefin, respectively. The band at $1074 \mathrm{~cm}^{-1}$ represents the C-I, C-N, C-F, C-O and aromatic C-H in plane bend and $821 \mathrm{~cm}^{-1}$ assigned the aromatic $\mathrm{C}-\mathrm{H}$ out of plane bend. In $\mathrm{BB}$, the band at $3415 \mathrm{~cm}^{-1}$ represents the $\mathrm{H}$-bonded $-\mathrm{OH}$ stretch hydroxyl group. The bands at 1588 and $1598 \mathrm{~cm}^{-1}$ assigned to aromatic ring stretch and at $1163 \mathrm{~cm}^{-1}$ aromatic $\mathrm{C}-\mathrm{H}$ in plane bend. In CM, the band at $3396 \mathrm{~cm}^{-1}$ represents the $\mathrm{H}$-bonded $-\mathrm{OH}$ stretch hydroxyl group. The band at $1417 \mathrm{~cm}^{-1}$ assigned to vinyl $\mathrm{C}-\mathrm{H}$ in plane bend, carboxylate and carbonate ion and $1077 \mathrm{~cm}^{-1}$ assigned to $\mathrm{C}-\mathrm{O}-\mathrm{C}$ cyclic ethers and C-O stretch, respectively. The bands at 1588 and $798 \mathrm{~cm}^{-1}$ represents the aromatic ring stretch and aromatic C-H out of plane bend, respectively. Surface area of the biochar ranged from 1.622 to $8.559 \mathrm{~m}^{2} \mathrm{~g}^{-1}$ (Table 2). 


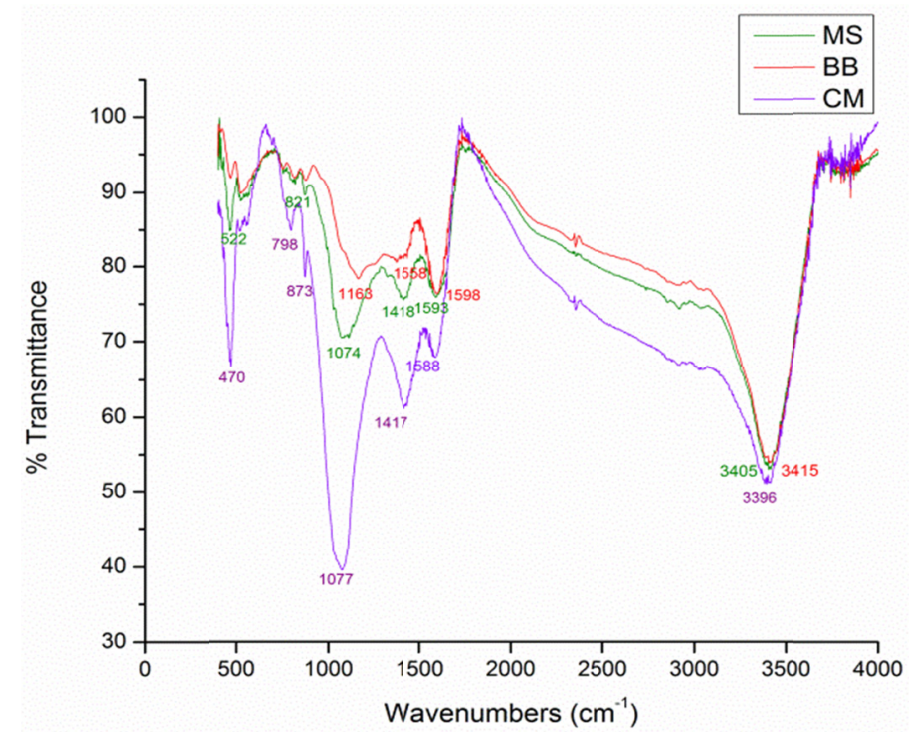

Figure 1. FTIR spectra of maize stalk (MS), bamboo (BB) and cow manure (CM) derived biochars

SEM images of biochar and their surface elemental analysis results are shown in Figure 2. The SEM images showed the irregular and porous surfaces of all biochar, although the MS and BB biochar showed relatively higher porous feature (Figure 2). The EDS spectrum of biochars showed that they have $\mathrm{C}$ and $\mathrm{O}$ dominated the surface of biochar with $\mathrm{Na}, \mathrm{Mg}, \mathrm{Al}, \mathrm{S}, \mathrm{Cl}$ and $\mathrm{Ca}$ present at different proportions (Figure 2).

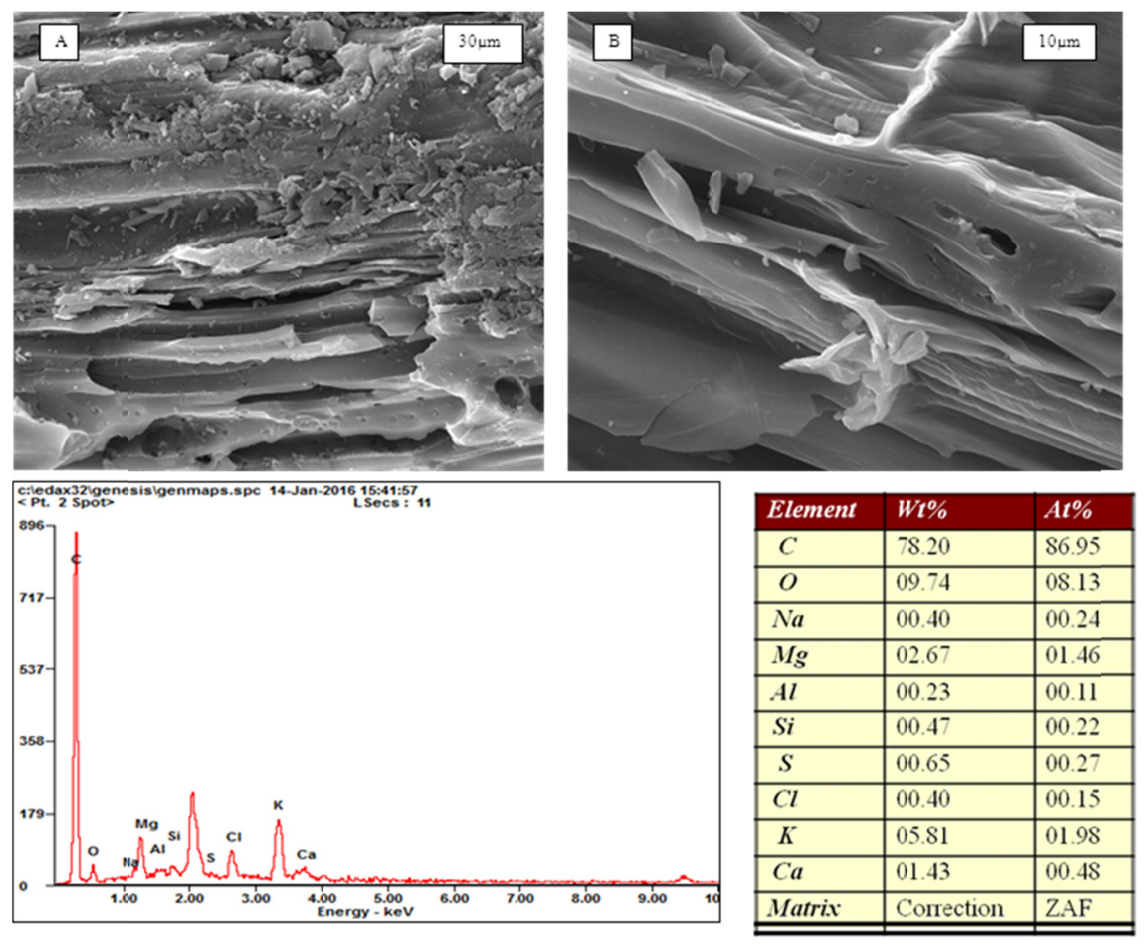



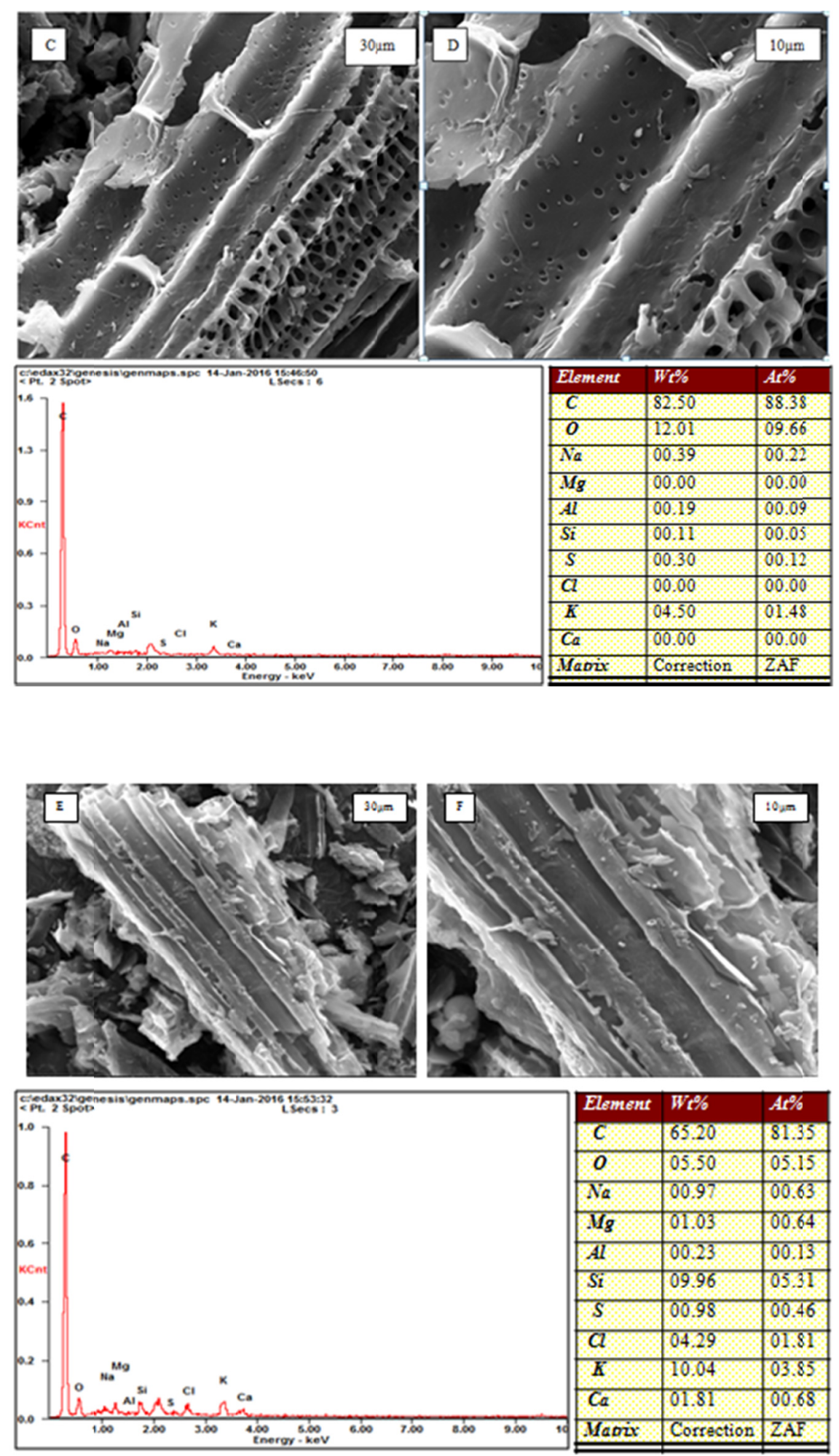

\begin{tabular}{|l|l|l|}
\hline Element & Wr\% & At\% \\
\hline$C$ & 65.20 & 81.35 \\
\hline$O$ & 05.50 & 05.15 \\
\hline $\mathrm{Na}$ & 00.97 & 00.63 \\
\hline $\mathrm{Mg}$ & 01.03 & 00.64 \\
\hline$A l$ & 00.23 & 00.13 \\
\hline $\mathrm{Si}$ & 09.96 & 05.31 \\
\hline$S$ & 00.98 & 00.46 \\
\hline $\mathrm{C}$ & 04.29 & 01.81 \\
\hline$K$ & 10.04 & 03.85 \\
\hline $\mathrm{Ca}$ & 01.81 & 00.68 \\
\hline $\mathrm{MaODix}$ & Correction & $\mathrm{ZAF}$ \\
\hline \hline
\end{tabular}

Figure 2. SEM images and Surface element analysis (EDS) of biochars; (A and B) maize stalk, (C and D) bamboo and $(\mathrm{E}$ and $\mathrm{F})$ cow manure derived biochars 


\subsection{Change in Soil pH}

Application of $\mathrm{CM}$ and MS biochar increased soil $\mathrm{pH}$ as they were alkaline in nature (Table 3). The highest mean value of $\mathrm{pH}$ occurred in soil treated with $\mathrm{MS}$ and $\mathrm{CM}$ biochar but $\mathrm{BB}$ had no effect on soil $\mathrm{pH}$, while the lowest values of $\mathrm{pH}$ were found in the control soil untreated with biochar.

Table 3. $\mathrm{pH}$, Mehlich-3 Extractable $\mathrm{Cd}$ and trace elements $\left(\mathrm{mg} \mathrm{kg}^{-1}\right)$ with and without biochar amendments

\begin{tabular}{llllll}
\hline Treatments & $\mathrm{pH}$ & $\mathrm{Cd}$ & $\mathrm{Mn}$ & $\mathrm{Zn}$ & $\mathrm{Fe}$ \\
\hline Soil & $7.33 \pm 0.03 \mathrm{c}$ & $0.76 \pm 0.11 \mathrm{a}$ & $35.31 \pm 1.16 \mathrm{~b}$ & $41.61 \pm 1.33 \mathrm{c}$ & $52.24 \pm 2.18 \mathrm{~b}$ \\
CM+SOIL & $7.70 \pm 0.03 \mathrm{~b}$ & $0.46 \pm 0.06 \mathrm{~b}$ & $55.82 \pm 1.62 \mathrm{a}$ & $61.09 \pm 2.04 \mathrm{~b}$ & $48.06 \pm 1.75 \mathrm{~b}$ \\
BB+SOIL & $7.38 \pm 0.02 \mathrm{c}$ & $0.42 \pm 0.03 \mathrm{~b}$ & $33.16 \pm 1.68 \mathrm{~b}$ & $64.03 \pm 1.47 \mathrm{~b}$ & $46.73 \pm 1.31 \mathrm{~b}$ \\
MS+SOIL & $7.78 \pm 0.02 \mathrm{a}$ & $0.35 \pm 0.04 \mathrm{~b}$ & $57.8 \pm 1.28 \mathrm{a}$ & $77.39 \pm 1.20 \mathrm{a}$ & $66.43 \pm 1.27 \mathrm{a}$ \\
\hline
\end{tabular}

Note. MB, BB and CM represents biochars derived from Maize stalk, bamboo and cow manure amended soil, respectively. Each value represents the mean of three replicates \pm standard error, and the different letters within the same column are significantly different at $p<0.05$.

\subsection{Bioavailability of $C d$ and Trace Metals in Soil}

Cadmium availability was significantly $(P<0.05)$ influenced by the application of biochar in soil and was very effective in reducing Cd extractability (Mehlic-3 extraction) (Table 3). Particularly, MS biochar showed higher decline in extractable $\mathrm{Cd}$ content by $54 \%$, as compared to the un-amended soil. While $\mathrm{BB}$ and $\mathrm{CM}$ biochar addition reduced $\mathrm{Cd}$ availability by $45 \%$ and $39 \%$, respectively.

The addition of biochar significantly $(P<0.05)$ effects the trace metal availability of $\mathrm{Cd}$ contaminated Alfisol soil (Table 3). The highest increase of trace metals occurred with addition of MS biochar as compared to the untreated soil by 26,94 and $86 \%$ for $\mathrm{Fe}, \mathrm{Mn}$ and $\mathrm{Zn}$, respectively.

\subsection{Effect of Biochar on DHA and BSR of Soil}

Application of biochar also considerably $(P<0.05)$ enhanced the DHA and SBR (Table 4). Addition of MS and $\mathrm{CM}$ biochar had the highest increased in soil respiration. DHA also increased more significantly $(P<0.05)$ with addition of $\mathrm{BB}$ and $\mathrm{CM}$ than MS biochar.

Table 4. Microbial activity (DHA and BSR) and Dry biomass $\left(\mathrm{g} \mathrm{plant}^{-1}\right)$ of shoots of B. chinensis L. cultivars Aijiaoheiye 333 (AJ) and Zhouyeheiyoudonger (ZH) grown on Alfisol soil with different biochar amendment

\begin{tabular}{|c|c|c|c|c|c|c|}
\hline \multirow{2}{*}{ Soil treatments } & \multicolumn{2}{|c|}{ Dry Biomass } & \multicolumn{2}{|c|}{ DHA } & \multicolumn{2}{|c|}{ BSR } \\
\hline & $\mathrm{AJ}$ & $\mathrm{ZH}$ & $\mathrm{AJ}$ & $\mathrm{ZH}$ & $\mathrm{AJ}$ & $\mathrm{ZH}$ \\
\hline SOIL & $1.75 \pm 0.07 b$ & $1.36 \pm 0.15 b$ & $1.98 \pm 0.05 \mathrm{c}$ & $1.98 \pm 0.04 \mathrm{c}$ & $0.55 \pm 0.01 \mathrm{c}$ & $0.6 \pm 0.01 \mathrm{~d}$ \\
\hline MS & $2.67 \pm 0.21 \mathrm{a}$ & $2.26 \pm 0.18 \mathrm{a}$ & $2.68 \pm 0.02 b$ & $2.67 \pm 0.01 b$ & $2.77 \pm 0.02 \mathrm{a}$ & $2.74 \pm 0.02 \mathrm{a}$ \\
\hline BB & $2.66 \pm 0.09 \mathrm{a}$ & $2.26 \pm 0.09 \mathrm{a}$ & $2.79 \pm 0.02 \mathrm{a}$ & $2.8 \pm 0.01 \mathrm{a}$ & $1.76 \pm 0.01 \mathrm{~b}$ & $1.89 \pm 0.01 \mathrm{c}$ \\
\hline $\mathrm{CM}$ & $2.66 \pm 0.15 \mathrm{a}$ & $2.43 \pm 0.18 \mathrm{a}$ & $2.87 \pm 0.02 \mathrm{a}$ & $2.85 \pm 0.02 \mathrm{a}$ & $2.81 \pm 0.01 \mathrm{a}$ & $2.58 \pm 0.01 \mathrm{~b}$ \\
\hline
\end{tabular}

Note. MB, BB and CM represents biochars derived from Maize stalk, bamboo and cow manure amended soil, respectively.

\subsection{Effect of Biochar on Plant Dry Biomass and Metals Accumulation}

As expected from the observed decrease $\mathrm{Cd}$ availability in soil, all the biochar were effective in decreasing $\mathrm{Cd}$ accumulation in the shoots of both cultivars of Chinese cabbage (Figure 3). MS and BB biochar were reduced Cd accumulation in shoots of AJ cultivar by 36 and $35 \%$, as compared to the control which did not receive amendment. In $\mathrm{ZH}$ cultivar, MS biochar had the highest reduction in $\mathrm{Cd}$ accumulation in shoots as compared to the control by $41 \%$. However, application of $\mathrm{BB}$ and $\mathrm{CM}$ biochar also reduced the concentration of $\mathrm{Cd}$ in shoots by 32 and $10 \%$, respectively. Cd concentration in roots was also affected by the addition of biochar in both cultivars of Chinese cabbage (Figure 3). The highest decrease in Cd content was recorded in roots of AJ grown in BB biochar amended soil as compared to the control and other biochar amendments, respectively. 

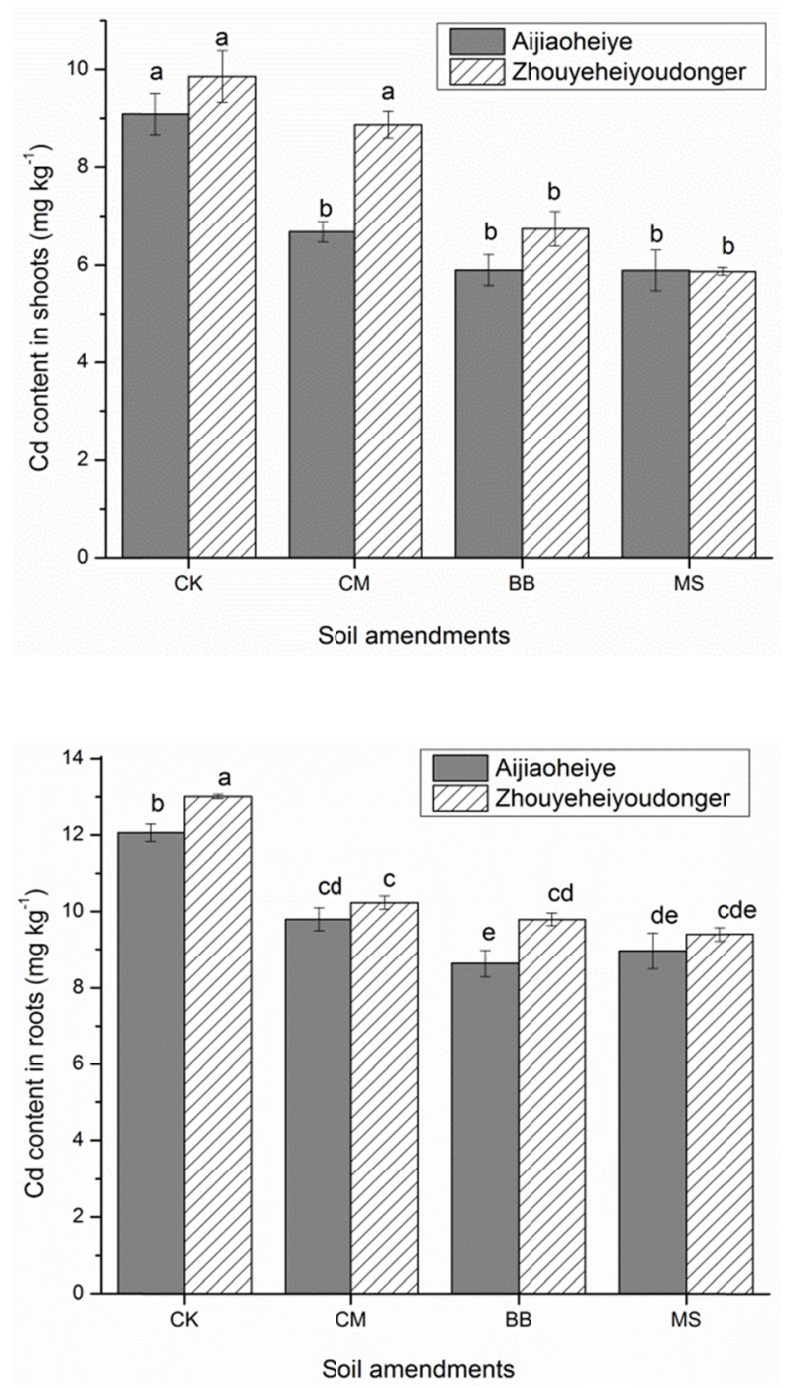

Figure 3. Effects of biochar amendments on Cd concentration in shoots and roots of B.chinensis L. cultivars: Aijiaoheiye 333 (AJ) and Zhouyeheiyoudonger (ZH). BB and CM represent biochars derived from maize stalk, bamboo and cow manure amended soil. Each value represents the mean of three replicates \pm standard error, and the different letters are significantly different at $p<0.05$

All biochar addition had also impacted on trace metal availability and accumulation in shoots of both cultivars of Chinese cabbage (Figure 4). Specifically, MS biochar significantly $(P<0.05)$ increased $\mathrm{Mn}$ and $\mathrm{Zn}$ content in shoots of AJ cultivar by $32 \%$ and $5 \%$ and $\mathrm{ZH}$ cultivars by $18 \%$ and $23 \%$. While, Fe concentration decreased in $\mathrm{AJ}$ by $45 \%$ and $26 \%$ in $\mathrm{ZH}$ cultivar with MS biochar addition with respect to their control. However, BB biochar addition had decreased the accumulation of $\mathrm{Zn}, \mathrm{Fe}$ and $\mathrm{Mn}$ in shoots of $\mathrm{ZH}$ cultivar while in shoots of AJ cultivar $\mathrm{Zn}$ and $\mathrm{Fe}$ increased by $17.8 \%$ and $32.4 \%$ but there was no effect on $\mathrm{Mn}$ as compared to the control. $\mathrm{CM}$ biochar increased $\mathrm{Mn}$ content in the shoots of $\mathrm{AJ}$ and $\mathrm{ZH}$ cultivars by $16 \%$ and $20 \%$ while decreased Fe accumulation by $43 \%$ and $31 \%$. 

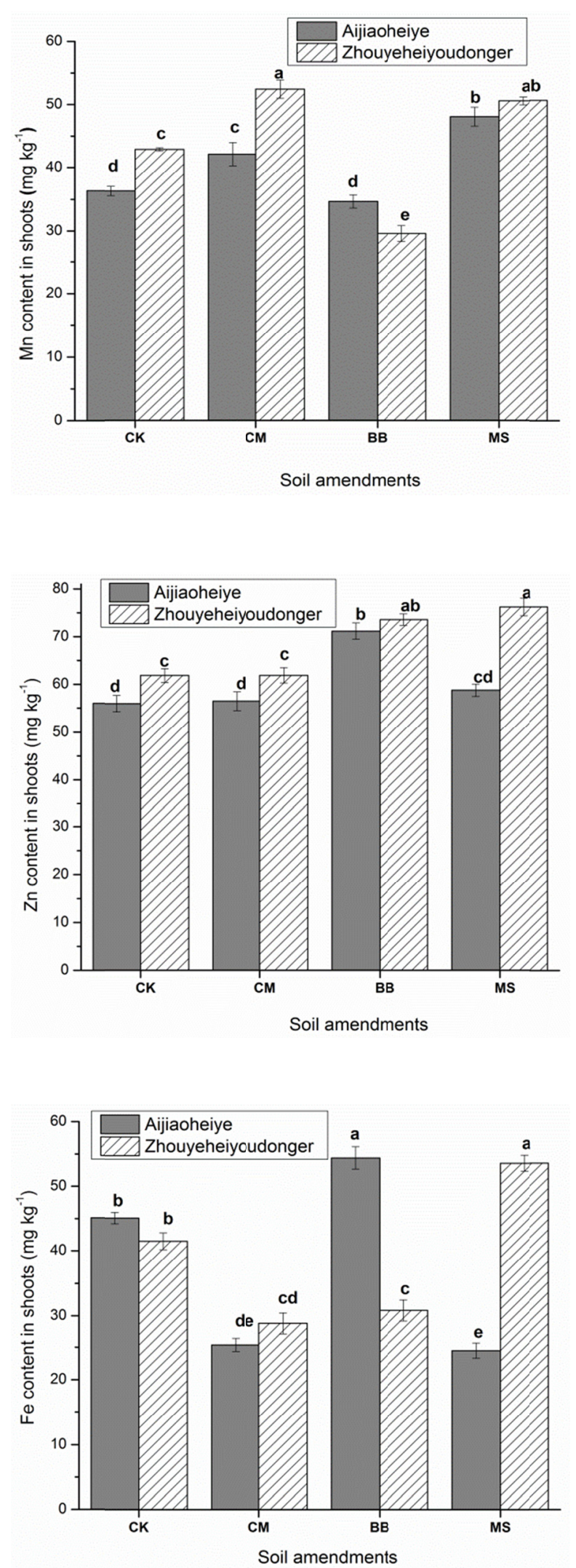

Figure 4. Mn, $\mathrm{Zn}$ and Fe concentration in shoots of B.chinensis L. cultivars Aijiaoheiye 333 (AJ) and Zhouyeheiyoudonger $(\mathrm{ZH})$ with soil amendments. BB and $\mathrm{CM}$ represent biochars derived from maize stalk, bamboo and cow manure amended soil. Each value represents the mean of three replicates \pm standard error, and the different letters are significantly different at $p<0.05$ 
The application of biochar significantly $(P<0.05)$ increased the dry biomass of plant shoots of both cultivars as compared to the control (Table 4). The addition of CM biochar increased the DW of ZH and AJ cultivars by 79 and $52 \%$. Both MS and BB biochar increased shoot DW of AJ and ZH by $52 \%$ and $66 \%$, respectively.

\section{Discussion}

Various studies have revealed that biochar used as a soil amendment are able to increase soil $\mathrm{pH}$ and induced liming effect (Lucchini et al., 2014; Ameloot et al., 2013; Nguyen \& Lehmann, 2009). Our results showed that biochar were primarily in the alkaline range and increased the soil $\mathrm{pH}$ except bamboo biochar which demonstrated that $\mathrm{pH}$ of biochar was dependent on the type of feedstock (Table 3). With increased biochar $\mathrm{pH}$ results increase in soil $\mathrm{pH}$ which directly enhanced the negative charge groups and this might be the reason that BB has no effect on soil pH. The alkalinity of biochar may be due to the separation of alkali salts during pyrolysis (Mohan et al., 2014) and the release of basic cations into the soil that could be responsible for increasing soil pH (Nguyen \& Lehmann, 2009). Application of MS and CM biochar increased the soil pH from 7.33 to 7.78 and 7.70 and subsequently immobilized $\mathrm{Cd}$ in an Alfisol soil; however, this increase could results in the precipitation of $\mathrm{Cd}$ as $\mathrm{Cd}(\mathrm{CO})_{3}$ (Mousavi et al., 2010).

Numerous studies have also been reported that application of biochar is effective in Cd immobilization, thereby reducing the bioavailability and phytotoxicity (Zhou et al., 2008; Namgay et al., 2010; Jiang et al., 2012). Mehlich-3 extractable $\mathrm{Cd}$ was found to be more improved indicator and used as soil $\mathrm{Cd}$ thresholds in Chinese cabbage for potential dietary toxicity (Rafiq et al., 2014). The effects of biochar on metal adsorption varied with the source material used to produce it and the type of metal. MS, BB and CM biochar amendment significantly declined the extractability of $\mathrm{Cd}$ in an Alfisol soil. $\mathrm{BB}$ biochar reduced the $\mathrm{Cd}$ availability even at neutral $\mathrm{pH}$. Similarly, it was reported that $\mathrm{BB}$ biochar can absorb $\mathrm{Cu}, \mathrm{Hg}, \mathrm{Ni}$, and $\mathrm{Cr}$ from both soils and water while $\mathrm{Cd}$ in polluted soils (Cheng et al., 2006; Skjemstad et al., 2002). The possible mechanism may be that the BB biochar has a high amount of amorphous $\mathrm{C}$, thereby supporting the formation of micropores and increasing the sorption capacity (Haghseresht et al., 1999).

Biochar could indirectly enhance plant growth through supplying nutrients and trace elements and improving soil physical and biological properties (Lehmann et al., 2006). Application of biochar (4\% w/w) significantly reduced $\mathrm{Cd}$ accumulation in both cultivars of Chinese cabbage and increased essential trace metals that may subsequently attribute to the increased plant biomass. Matovic (2010) also reported that in agricultural soil, optimum biochar addition ranged between 1 to $5 \% \mathrm{w} / \mathrm{w}$ of soil. The overall addition of MS, CM and BB biochar had a positive effect on plant growth i.e increased the dry weight of shoot as compared to the control (untreated with biochar). Similarly, the application of Eucalyptus spp. wood chips derived biochar produced higher biomass of spring onion as compared to cultivated in control soils (Yu et al., 2009).

With the MS, CM and BB biochar amendment, Cd concentration significantly reduced in shoots and roots of $\mathrm{Cd}$ accumulating contrasting cultivars of Chinese cabbage. MS and BB had more decline in Cd accumulation and facilitate more essential trace metal concentration in shoots of both cultivars than CM. Similarly, Lehmann et al. (2003) also reported that application of biochar increased plant yield and this increase attributed to the increase in soil available nutrients. Park et al. (2011) also reported that biochar application resulting in increased plant biomass and reduced metal uptake in plants because of dilution and immobilization of metals.

In this study, MS biochar had the highest $\mathrm{N}$ content while BB biochar had lowest. However, in previous studies it has been observed that $\mathrm{N}$ contents in biochar depend on feedstock types, as plant material derived biochar had more $\mathrm{C}$ and $\mathrm{N}$ than animal manure derived biochar (Ahmad et al., 2014; Gaskin et al., 2008). MS and BB biochar were showed higher $\mathrm{C} / \mathrm{N}$ ratio than $\mathrm{CM}$ biochar, such events has been attributed to aromaticity of biochar and will cause slow decomposition and higher stability in soil (Lehman, 2007). Hence, it seems that BB biochar would have the longest stability, whereas CM biochar has the least stability in soil. This was attributed to the high lignin content of bamboo which contributes to the high content of aromatic $\mathrm{C}$ of biochar (Cesarino et al., 2012).

However, the total $\mathrm{H}$ and $\mathrm{C}$ were notably higher in $\mathrm{BB}$ and $\mathrm{MS}$ biochar as compared to the $\mathrm{CM}$ biochar. Whereas, in this study all biochar had same $\mathrm{H} / \mathrm{C}$ ratio and indicating lower aromatic structure while increase occurred in the preserved organic $\mathrm{C}$ because higher $\mathrm{H} / \mathrm{C}$ ratios of biochar specified lower carbonization and aromaticity (Mohan et al., 2014). Lower aromatic structure as a result may have more sorption sites for inorganic contaminants (Ahmad et al., 2014; Chen et al., 2001). In reducing availability and uptake of Cd, the MS and BB biochar were more effective than CM biochar which had a larger surface area. According to Cui et al. (2016) Zizania caduciflora and Vetiveria zizanioides derived biochar had a larger surface area but lower sorption capacity of ammonium. In our results, the EDS spectrum of biochar showed that $\mathrm{C}$ and $\mathrm{O}$ dominated the surfaces 
of biochar, suggesting that they have more $\mathrm{C}$ and $\mathrm{O}$ bonds which adsorbed $\mathrm{Cd}$ from soil. SEM images also showed a highly porous surface of plant derived biochar which indicated the more sorption capacity of heavy metals. The functional groups of biochar also have a significant role in $\mathrm{Cd}$ sorption. A large number of functional groups mentioned in FTIR analysis were responsible for the adsorption of Cd. It was reported that biochar could adsorb heavy metal ions due to the presence of many functional groups including phenolic, carboxyl, and hydroxyl groups in its carbon-based structure (Bogusz et al., 2015; Jeong et al., 2012). The FTIR spectra of MS, $\mathrm{BB}$ and $\mathrm{CM}$ (Figure 1) indicated that adsorption attributed may be due to coordination of $-\mathrm{OH}, \mathrm{C}=\mathrm{C}-\mathrm{C}, \mathrm{C}-\mathrm{H}$, $\mathrm{C}-\mathrm{O}, \mathrm{C}-\mathrm{O}-\mathrm{C}$ groups exhibited on the surface of biochar because surface complex of $\mathrm{Cd}$ with oxygen-containing groups of biochar considerably contributes to $\mathrm{Cd}^{2+}$ sorption (Cui et al., 2016). Similarly, Ahmad et al. (2014) and $\mathrm{Xu}$ et al. (2013) reported that $\mathrm{O}$ containing groups could form strong surface complexes with $\mathrm{Cd}$. However, contradictory explanations have been reported on the mobility of metals within biochar (Beesley et al., 2010). Therefore, specifically detailed studies on metal binding and their transformation are still required to understand the mechanism.

Soil basal respiration (SBR) and Dehydrogenase activity (DHA) are interrelated and key parameters for the rapid measurement of changes in soil fertility and determination of the intensity of microbial metabolism in soil (Trasar-Cepeda et al., 2012). Application of MS, BB and CM biochar improved the soil basal respiration and dehydrogenase activity which may also contribute to decrease the $\mathrm{Cd}$ bioavailability, phytotoxicity and enhanced phytobioavailability of essential trace metals. The application of biochar enhanced soil microbial activity and microbial population have also been previously observed (Verheijen et al., 2010; Lehmann et al., 2011), even though the mechanism is not fully understood for biochar induced stimulation of microbial activity (Warnock et al., 2007). Similarly, green waste and chicken manure derived biochar amendment also considerably decreased $\mathrm{Cd}$ and $\mathrm{Pb}$, stimulated microbial activity, nutrients uptake and plant growth which may be due to enhanced soil respiration (Park et al., 2011).

\section{Conclusion}

Application of MS, BB and CM derived biochar as soil amendment for immobilization of Cd were promising materials for agricultural soils by altering chemical properties of soil. The results have clearly confirmed that biochar amendment to $\mathrm{Cd}$ contaminated Alfisol soil has the potential to suppress the bioavailability and phytotoxicity. In addition, biochar amendment enhanced plant growth and dry biomass by improving essential trace metal availability. Plant derived biochar were more effective than cow manure derived biochar in $\mathrm{Cd}$ immobilization and increasing phytoavailability of trace metals and may be due to lower $\mathrm{C} / \mathrm{N}$ ratio and higher $\mathrm{H}$ and $\mathrm{C}$ contents of MS and BB biochar. Therefore, biochar has the potential to reduce the $\mathrm{Cd}$ uptake in both cultivars of $B$. chinensis L. which could be used to lower the human health risk caused by the $\mathrm{Cd}$ contamination. In this study biochar were effective to reduce $\mathrm{Cd}$ and increase the $\mathrm{Zn}, \mathrm{Mn}$ and Fe availability into the plant soil system even though it varies depending on the type of biochar. However, further additional field study required to explore the applications of findings and sustainability of biochar in an Alfisol soil.

\section{Acknowledgements}

This work was financially supported by a grant from the Ministry of Science and Technology of China (No. 2012AA100405) and from University innovative research funds (No. 2015FZA6008). K.Y. Khan acknowledges China Scholarship Council for providing a PhD scholarship under China Government Scholarship Programme.

\section{References}

Ahmad, M., Rajapaksha, A. U., Lim, J. E., Zhang, M., Bolan, N., Mohan, D., Vithanage, M., ... Ok, Y. S. (2014). Biochar as a sorbent for contaminant management in soil and water, A review. Chemosphere, 99, 19-33. http://dx.doi.org/10.1016/j.chemosphere.2013.10.071

Ameloot, N., De Neve, S., Jegajeevagan, K., Yildiz, G., Buchan, D., Funkuin, Y. N., ... Sleutel, S. (2013). Short-term $\mathrm{CO}_{2}$ and $\mathrm{N}_{2} \mathrm{O}$ emissions and microbial properties of biochar amended sandy loam soils. Soil Biol. Biochem., 57, 401-410. http://dx.doi.org/10.1016/j.soilbio.2012.10.025

Amonette, J. E., \& Joseph, S. (2009). Characteristics of Biochar, Microchemical Properties. In J. Lehmann \& S. Joseph (Eds.), Biochar for Environmental Management, Science and Technology (pp. 33-52), Earthscan, London.

Beesley, L., Jimenez, E. M., \& Eyles, J. L. G. (2010). Effects of biochar and greenwaste compost amendments on mobility, bioavailability and toxicity of inorganic and organic contaminants in a multi-element polluted soil. Environ. Pollut., 158, 2282-2287. http://dx.doi.org/10.1016/j.envpol.2010.02.003 
Bogusz, A., Oleszczuk, P., \& Dobrowolski, R. (2015). Application of laboratory prepared and commercially available biochars to adsorption of cadmium, copper and zinc ions from water. Bioresource Technology, 196, 540-549. http://dx.doi.org/10.15376/biores.9.1.685-703

Trasar-Cepeda, C., Hernández, T., García, C., Rad, C., \& González-Carcedo, S. (2012). Soil Enzymology in the Recycling of Organic Wastes and Environmental Restoration, Environmental Science and Engineering. Springer-Verlag Berlin Heidelberg. http://dx.doi.org/10.1007/978-3-642-21162-1_7

Casida, L. E. J., Klein, D. A., \& Santoro, T. (1964). Soil dehydrogenase activity. Soil Sci., 98, $371-376$. http://dx.doi.org/10.1023/A:1004182329826

Cesarino, I., Araújo, P., Domingues Júnior, A. P., \& Mazzafera, P. (2012). An overview of lignin metabolism and its effect on biomass recalcitrance. Braz. J. Bot., 35, 303-311. http://dx.doi.org/10.1590/ S0100-84042012000400003

Chen, J. P., \& Lin, M. (2001). Equilibrium and kinetics of metal ion adsorption onto a commercial H-type granular activated carbon, experimental and modeling studies. Water Res., 35, 2385-2394. http://dx.doi.org/ 10.1016/S0043-1354(00)00521-2

Chen, Y., Li, T., Han, X., Ding, Z., Yang, X., \& Jin, Y. F. (2012). Cadmium accumulation in different pakchoi cultivars and screening for pollution-safe cultivars. J. Zhejiang Univ-Sci. B (Biomed. \& Biotechnol.), 13(6), 494-502.

Cheng, C. H., Lehmann, J., Thies, J. E., Burton, S. D., \& Engelhard, M. H. (2006). Oxidation of black carbon by biotic and abiotic processes. Organ. Geochem., 37, 1477-1488. http://dx.doi.org/10.1016/j.orggeochem.2006.06.022

Coates, J. (2000). Interpretation of Infrared Spectra, A Practical Approach. In R. A. Meyers (Ed.), Encyclopedia of Analytical Chemistry (pp. 10815-10837).

Cui, X., Hao, H., Zhang, C., He, Z., \& Yang, X. (2016). Capacity and mechanisms of ammonium and cadmium sorption on different wetland-plant derived biochar. Science of the Total Environment, 539, 566-575. http://dx.doi.org/10.1016/j.scitotenv.2015.09.022

Fang, Y., Cao, X., \& Zhao, L. (2012). Effects of phosphorus amendments and plant growth on the mobility of Pb, $\mathrm{Cu}$, and $\mathrm{Zn}$ in a multi-metal-contaminated soil. Environ. Sci. Pollut. Res., 19, 1659-1667. http://dx.doi.org/ 10.1007/s11356-011-0674-2

Gaskin, J. W., Steiner, C., Harris, K., Das, K. C., \& Bibens, B. (2008). Effect of low-temperature pyrolysis conditions on biochar for agricultural use. Transaction of American Society of Agricultural and Biological Engineers, 51(6), 2061-2069. http://dx.doi.org/10.1002/jpln.200390028

Haghseresht, F., Lu, G., \& Whittaker, A. (1999). Carbon structure and porosity of carbonaceous adsorbents in relation to their adsorption properties. Carbon, 37, 1491-1497. http://dx.doi.org/10.1007/s10661-0144093-y

Hänsch, R., \& Mendel, R. R. (2009). Physiological functions of mineral micronutrients (Cu, Zn, Mn, Fe, Ni, Mo, B, Cl). Curr. Opin. Plant Biol., 12, 259-266. http://dx.doi.org/10.1016/j.pbi.2009.05.006

Hebbern, C. A., Laursen, K. H., Ladegaard, A. H., Schmidt, S. B., Pedas, P., Bruhn, D., ... Husted, S. (2009). Latent manganese deficiency increases transpiration in barley (Hordeum vulgare). Physiol. Plant., 135, 307-316. http://dx.doi.org/10.1111/j.1399-3054.2008.01188

Inyang, M., Gao, B., Yao, Y., Xue, Y., Zimmerman, A. R., \& Pullammanappallil, P. (2012). Removal of heavy metals from aqueous solution by biochars derived from anaerobically digested biomass. Bioresour. Technol., 110, 50-56. http://dx.doi.org/10.1016/j.biortech.2012.01.072

Islam, K. R., \& Weil, R. R. (2000). Land use effects on soil quality in a tropical forest ecosystem of Bangladesh. Agriculture, Ecosystem \& Environment, 79, 9-16. http://dx.doi.org/10.1016/S0167-8809(99)00145-0

Jeong, C. Y., Wang, J. J., Dodla, S. K., Eberhardt, T. L., \& Groom, L. (2012). Effect of biochar amendment on tylosin adsorption-desorption and transport in two different soils. J. Environ. Qual., 41, 1185-1192. http://dx.doi.org/10.2134/jeq2011.0166

Jiang, T. Y., Jiang, J., Xu, R. K., \& Li, Z. (2012). Adsorption of Pb(II): On variable charge soils amended with rice-straw derived biochar. Chemosphere, 89, 249-256. http://dx.doi.org/10.1016/j.chemosphere.2012. 04.028 
Lee, J. S., Chon, H. T., \& Kim, K. W. (2005). Human risk assessment of As, Cd, Cu and Zn in the abandoned metal mine site. Environ. Geochem. Health, 27, 185-191. http://dx.doi.org/10.1007/s11356-015-4368-z

Lehmann, J. (2007). A handful of carbon. Nature, 447, 143-144. http://dx.doi.org/10.1016/S1001-0742(09) 60080-2

Lehmann, J., Gaunt, J., \& Rondon, M. (2006). Biol.-char sequestration in terrestrial ecosystems-A review. Mitigation and Adaptation Strategies for Global Change, 11, 403-427. http://dx.doi.org/10.1007/ s11027-005-9006-5

Lehmann, J., Pereira da Silva, J., Steiner, Jr. C., Nehls, T., Zech, W., \& Glaser, B. (2003). Nutrient availability and leaching in an archaeological Anthrosol and a Ferralsol of the Central Amazon basin: Fertilizer, manure and charcoal amendments. Plant Soil, 249, 43-357. http://dx.doi.org/10.1023/A:1022833116184

Lehmann, J., Rillig, M. C., Thies, J., Masiello, C. A., Kockaday, W. C., \& Crowley, D. (2011). Biochar effects on soil biota-A review. Soil Biol. Biochem., 43, 1812-1836. http://dx.doi.org/10.1016/j.soilbio.2008.10.016

Liu, H., Probst, A., \& Liao, B. (2005). Metal contamination of soils and crops affected by the Chenzhou lead/zinc mine spill (Hunan, China). Sci. Total Environ., 339, 153-166. http://dx.doi.org/10.1016/ j.scitotenv.2004.07.030

Liu, W., Zhou, Q., An, J., Sun, Y., \& Liu, R. (2010). Variations in cadmium accumulation among Chinese cabbage cultivars and screening for Cd-safe cultivars. Journal of Hazardous Materials, 173, 737-743. http://dx.doi.org/10.1016/j.jhazmat.2009.08.147

Lucchini, P., Quilliam, R. S., DeLuca, T. H., Vamerali, T., \& Jones, D. L. (2014). Does biochar application alter heavy metal dynamics in agricultural soil? Agric. Ecosyst. Environ., 184, 149-157. http://dx.doi.org/10.1016/j.agee.2013.11.018

Matovic, D. (2010). Biochar as a viable carbon sequestration option, global and Canadian perspective. Energy, 36, 2011-2016. http://dx.doi.org/10.1016/j.energy.2010.09.031

Mendez, A., Gomez, A., Paz-Ferreiro, J., \& Gasco, G. (2012). Effects of sewage sludge biochar on plant metal availability after application to a Mediterranean soil. Chemosphere, 89, 1354-1359. http://dx.doi.org/10.1016/j.chemosphere.2012.05.092

Mehlich, A. (1984). Mehlich-3 soil test extractant-A modification of Mehlich-2 extractant. Commun. Soil Sci. Plant Anal., 15, 1409-1416. http://dx.doi.org/10.1080/00103628409367568

Mohan, D., Sarswat, A., Ok, Y. S., \& Pittman, Jr. C. U. (2014). Organic and inorganic contaminants removal from water with biochar, a renewable, low cost and sustainable adsorbent-A critical review. Bioresource Technology, 160,191-202. http://dx.doi.org/10.1016/j.biortech.2014.01.120

Mousavi, H. Z., Hosseinifar, A., \& Jahed, V. (2010). Removal of Cu(II): From wastewater by waste tire rubber ash. J. Serb. Chem. Soc., 75, 845-753. http://dx.doi.org/10.2298/JSC090410044M

Namgay, T., Singh, B., \& Singh, B. P. (2010). Influence of biochar application to soil on the availability of As, Cd, $\mathrm{Cu}, \mathrm{Pb}$, and $\mathrm{Zn}$ to maize (Zea mays L.). Aust. J. Soil Res., 48, 638-647. http://dx.doi.org/10.1071/SR10049

Nguyen, B. T., \& Lehmann, J. (2009). Black carbon decomposition under varying water regimes. Org. Geochem., 40, 846-853. http://dx.doi.org/10.1016/j.orggeochem.2009.05.004

Park, J. H., Choppala, G. K., Bolan, N. S., Chung, J. W., \& Chuasavathi, T. (2011). Biochar reduces the bioavailability and phytotoxicity of heavy metals. Plant Soil, 348, 439-451. http://dx.doi.org/10.1007/ s11104-011-0948-y

Rafiq, M. T., Aziz, R., Yang, X., Xiao, W., \& Stoffella, P. J. (2014). Phytoavailability of Cadmium (Cd): To Pak Choi (Brassica chinensis L.): Grown in Chinese Soils, A Model to Evaluate the Impact of Soil Cd Pollution on Potential Dietary Toxicity. PloS ONE, 9(11). http://dx.doi.org/10.1371/journal.pone.0111461

Rashid, A., Ryan, J., \& Estefan, G. (2001). Soil and Plant Analysis Laboratory Manual. International Center for Agricultural Research in the Dry Areas (ICARDA), Aleppo, Syria.

Sebastian, A., \& Prasad, M. N. V. (2014). Vertisol prevent cadmium accumulation in rice, analysis by ecophysiological toxicity markers. Chemosphere, 108, 85-92. http://dx.doi.org/10.1016/ j.chemosphere.2014.02.077 
Shentu, J., He, Z., Yang, X., \& Li, T. Q. (2008). Accumulation properties of cadmium in a selected vegetable -rotation system of south eastern China. J. Agric. Food Chem., 56, 6382-6388. http://dx.doi.org/10.1021/jf800882q

Singh, J., \& Singh, D. K. (2005). Dehydrogenase and phosphomono-esterase activities in groundnut (Arachis hypogaea L.): field after diazinon, imidacloprid and lindane treatments. Chemosphere, 60, 32-42. http://dx.doi.org/10.1016/j.chemosphere.2004.11.096

Skjemstad, J. O., Reicosky, D. C., McGowan, J. A., \& Wilts, A. R. (2002). Charcoal carbon in U.S. agricultural soils. Soil Sci. Soc. Am. J., 66, 1249-1255. http://dx.doi.org/10.2136/sssaj2002.1249

Tang, J., Xiao, T. F., Wang, S. J., Lei, J. L., Zhang, M. Z., Gong, Y. Y., ... He, L. B. (2009). High cadmium concentrations in areas with endemic fluorosis, a serious hidden toxin? Chemosphere, 76, 300-305.http://dx.doi.org/10.1016/j.chemosphere.2009.03.064

Tang, J., Zhu, W., Kookana, R., \& Katayama, A. (2013). Characteristics of biochar and its application in remediation of contaminated soil. J. Biosci. Bioeng., 116, 653-659. http://dx.doi.org/10.1016/j.jbiosc.2013. 05.035

Tang, X., Li, X., Liu, X., Hashmi, M. Z., Xu, J., \& Brookes, P. C. (2015). Effects of inorganic and organic amendments on the uptake of lead and trace elements by Brassica chinensis grown in an acidic red soil. Chemosphere, 119, 177-183. http://dx.doi.org/10.1016/j.chemosphere.2014.05.081

Verheijen, F., Jeffery, S., Bastos, A. C., van der Velde, M., \& Diafas, I. (2010). Biochar application to soils. A Critical Scientific Review of Effects on Soil Properties, Processes and Functions. European Commission, Italy.

Warnock, D. D., Lehmann, J., Kuyper, T. W., \& Rilling, M. C. (2007). Mycorrhizal responses to biochar in soil-Concepts and mechanisms. Plant Soil, 300, 9-20. http://dx.doi.org/10.1007/s11104-007-9391-5

Xiao, D. (1992). Alfisols and closely related soils in China. Chinese Geographical Science, 2(1), 18-29. http://dx.doi.org/10.1007/BF02664543

Xu, X., Cao, X., Zhao, L., Wang, H., Yu, H., \& Gao, B. (2013). Removal of Cu, Zn and Cd from aqueous solutions by the dairy manure-derived biochar. Environ. Sci. Pollut. Res. Int., 20(1), 358-368. http://dx.doi.org/10.1007/s11356-012-0873-5

Yan, S., Ling, Q., Bao, Z., Chen, Z., Yan, S., Dong, Z., ... Deng, B. (2009). Cadmium accumulation in pak choi (Brassica chinensis L.) and estimated dietary intake in the suburb of Hangzhou city, China. Food Addi. Contam., B2, 74-78.

Yang, J. X., Guo, H. T., Ma, Y. B., Wang, L. Q., \& Wei, D. P. (2010). Genotypic variations in the accumulation of exhibited by different vegetables. J. Environ. Sci., 22, 1246-1252. http://dx.doi.org/10.1016/S1001-0742 (09)60245-X

Yu, X. Y., Ying, G. G., \& Kookana, R. S. (2009). Reduced plant uptake of pesticides with biochar additions to soil. Chemosphere, 76, 665-671. http://dx.doi.org/10.1016/j.chemosphere.2009.04.001

Zhou, J. B., Deng, C. J., Chen, J. L., \& Zhang, Q. S. (2008). Remediation effects of cotton stalk carbon on cadmium (Cd) contaminated soil. Ecol. Environ., 17, 1857-1860. http://dx.doi.org/10.2134/jeq2012.0019

\section{Copyrights}

Copyright for this article is retained by the author(s), with first publication rights granted to the journal.

This is an open-access article distributed under the terms and conditions of the Creative Commons Attribution license (http://creativecommons.org/licenses/by/4.0/). 